\title{
$N A C$ transcription factor expression, amino acid concentration and growth of elite rice cultivars upon salt stress
}

\author{
Soledad García-Morales • Fernando Carlos Gómez-Merino • \\ Libia Iris Trejo-Téllez
}

Received: 25 September 2013/Revised: 27 March 2014/ Accepted: 30 April 2014/Published online: 5 June 2014

(C) The Author(s) 2014. This article is published with open access at Springerlink.com

\begin{abstract}
NAC transcription factors (TF) play important roles in regulating osmotic stress tolerance in plants. We tested the expression of 57 NAC genes in the presence of $\mathrm{NaCl}$ in young leaves of two elite rice cultivars, Cotaxtla and Tres Ríos, which display contrasting responses to salinity at the biochemical and physiological levels. Using qRT-PCR, the expression of 41 out of 57 NAC genes was validated, of which 23 showed regulation by $\mathrm{NaCl}$. We identified two NAC genes (OsO2g56600 and Os12g07790) induced in Cotaxtla, but repressed in Tres Ríos when plants were exposed to $100 \mathrm{mM} \mathrm{NaCl}$ in nutrient solution. In both elite cultivars, treated plants showed higher concentrations of total amino acids and proline in comparison to the controls; in all cases, Cotaxtla plants accumulated more free amino acids and proline than Tres Ríos plants. Furthermore, shoot growth was more affected in both cultivars, while root length was not reduced in treated plants in comparison to the controls. We conclude that both elite rice cultivars exhibit different expression patterns of NAC transcription factors as well as biochemical and
\end{abstract}

Communicated by A. Chandra.

Electronic supplementary material The online version of this article (doi:10.1007/s11738-014-1569-x) contains supplementary material, which is available to authorized users.

S. García-Morales · L. I. Trejo-Téllez

Colegio de Postgraduados, Campus Montecillo, Carretera

México-Texcoco km. 36.5, CP 56230 Montecillo,

Estado de México, Mexico

F. C. Gómez-Merino ( $\square)$

Colegio de Postgraduados, Campus Córdoba, Carretera

Córdoba-Veracruz km. 348, CP 94961 Amatlán de los Reyes,

Veracruz, Mexico

e-mail: fernandg@colpos.mx physiological responses to salt stress, giving rise to better performance of Cotaxtla plants in comparison to Tres Ríos plants under our experimental conditions.

Keywords Gene expression - Quantitative RT-PCR . Oryza sativa $\cdot$ Osmotic stress $\cdot$ Salinity

\section{Introduction}

Abiotic factors such as high salinity negatively affect plant growth and productivity as a consequence of the osmotic stress they cause. To cope with such environmental adversities, plants have developed a variety of molecular, biochemical and physiological mechanisms that include the activation of transcription factors (TF), which bind to specific cis-acting elements in the promoter region of target genes, thereby activating or repressing the transcriptional rates of such genes. The NAC (NAM, $\underline{A T A F}$ and $\underline{C U C})$ is a plant-specific transcription factor superfamily associated with diverse biological processes in plants, including growth and development, as well as responses to biotic and abiotic constraints (Puranik et al. 2012; Nuruzzaman et al. 2013), including salinity, drought and low temperature (Liu et al. 2014; Mao et al. 2012; Nuruzzaman et al. 2013). Indeed, the overexpression of ANACO19, ANAC055, and ANAC072 increased drought tolerance in transgenic plants by changing the transcription of a limited number of nonspecific salt- and drought-responsive genes (Tran et al. 2004), while plants overexpressing the $S N A C l$ gene possessed enhanced salt and drought tolerance and grain yield in the field test (Hu et al. 2006) by improving rice development and reducing transpiration rates (Liu et al. 2014). Though important progress in elucidating the roles of NAC transcription factors in plant abiotic stress has been made, a 
meticulous characterization of $N A C$ gene responses is crucial in conferring broad stress tolerance to plants. Interestingly, Mao et al. (2014) reported that TaNAC67, a novel NAC TF, confers enhanced multi-abiotic stress tolerances in Arabidopsis, and Chen et al. (2014) found that the NAC TF OsNAP plays an important role in mediating abiotic stress responses in rice through the ABA pathway. Just recently, to clarify the orthologous relationships among NAC genes of different species, Cenci et al. (2014) performed an in-depth comparative study of four divergent taxa: Arabidopsis thaliana, Vitis vinifera, Musa acuminata and Oryza sativa. Due to independent evolutionary processes, they found that NAC copy number is highly variable in these plant genomes and emphasized that this report provided a useful reference for NAC function studies in newly sequenced genomes.

Some NAC genes identified in crop plants have shown induction by high salinity stress (Ramegowda et al. 2012; Saad et al. 2013; Sperotto et al. 2009; Zhong et al. 2012), although they may be differently regulated as they contain diverse cis-acting elements in their promoter regions (Nakashima et al. 2007, 2012; Nuruzzaman et al. 2010). However, a complete understanding of the molecular network regulating rice responses to abiotic stress remains unclear, and few of these genes have been characterized to date, thus substantial experimental work will be required to determine the specific biological importance of each one. At the physiological and biochemical levels, the elite rice cultivars Cotaxtla and Tres Ríos have been shown to display contrasting responses to salt stress (García-Morales et al. 2012), with the cultivar Cotaxtla being classified as tolerant. As the vegetative phase is crucial for plant development, growth, and productivity, the expression pattern of 57 rice $N A C$ coding genes when exposed to salinity was analyzed in leaves of 34-day-old Cotaxtla and Tres Ríos plants grown hydroponically. Furthermore, we also evaluated concentrations of total amino acids and proline, as well as plant growth parameters, in an attempt to explain more in depth such contrasting responses showed by these rice cultivars.

\section{Materials and methods}

Rice cultivars and experimental conditions

The two elite rice (Oryza sativa L. spp. indica) cultivars (Cotaxtla and Tres Ríos) were obtained from the National Institute of Forestry, Agriculture, and Livestock Research (INIFAP), Zacatepec, Mexico. Rice seeds were sown in glass bottles containing MS medium, and 14 days after sowing they were transferred to $9 \mathrm{~L}$ tanks containing a nutrient solution as described by García-Morales et al.
(2012). Plants were grown hydroponically in a greenhouse (mean temperature $25^{\circ} \mathrm{C}$, range $18-32^{\circ} \mathrm{C}$ ) under natural light conditions ( $8 \mathrm{~h}$ dark) and $70 \%$ relative humidity. At day 20 after transferring plants to hydroponic conditions, salt treatments were applied by adding either 0 or $100 \mathrm{mM} \mathrm{NaCl}$ to the growth media. The second and third leaves under the flag leaf were sampled each 3 or $6 \mathrm{~h}$ after treatment, with control samples collected in parallel. After harvesting, the samples were immediately frozen in liquid nitrogen and stored at $-80{ }^{\circ} \mathrm{C}$ until used. Salt treatments were applied in two independent biological replicates.

RNA extraction, DNAse digestion and cDNA synthesis

Leaf samples from two biological replicates derived from six plants each were pooled to isolate total RNA using the SV total RNA Isolation System Kit (Progema), according to the manufacturer's protocol, which includes a DNAse treatment. Purified RNA was quantified spectrophotometrically and analyzed by denaturing in $1 \%(\mathrm{w} / \mathrm{v})$ agarose gel. Absence of genomic DNA contamination was confirmed using qRT-PCR, as described by Caldana et al. (2007). cDNA was synthesized from $4.5 \mu \mathrm{g}$ total RNA using Superscript ${ }^{\mathrm{TM}}$ III reverse transcriptase (Life Technologies), according to the manufacturer's protocol. Each experiment had two technical replicates, using cDNA synthesized from both cultivars harvested during two independent experimental tests.

Primers for target and reference genes and qRT-PCR analysis

$N A C$ transcription factor gene primer sequences were extracted from the complete list of $\mathrm{TF}$ gene primers reported by Caldana et al. (2007) and used to establish the expression profiling approach. In addition, the expression of the gene OsNAC10 (Os11g03300; AK069257) (Jeong et al. 2010) was tested as a positive control. Reference gene models tested were: actin (Os03g50890), actin1 (Os05g36290), $\beta$-tubuline (Os03g50890) and elongation factor $1 \alpha(O s 03 g 55270)$. All data concerning primers used are included in Supplementary File 1. Quantitative RTPCR conditions and analysis were performed as described by Caldana et al. (2007) in an ABI PRISM 7900 HT sequence detector system (Applied Biosystems). Expression stability values $(M)$ of reference genes were calculated according to Vandesompele et al. (2002). In accordance with Le et al. (2011) and considering the biological significance of the differential expression in this study, we adopted a cut-off value of twofold when analyzing stress induction or repression. The expression levels were 
designated as 'induced' or 'repressed' only if such differences met the above criteria and passed the Student's $t$ test.

Amino acid extraction and analysis

Fresh leaves were collected 15 days after $\mathrm{NaCl}$ treatments $(0$ or $100 \mathrm{mM})$. Total free amino acids and proline content were determined by a ninhydrin assay at $\mathrm{A}_{520} \mathrm{~nm}$ according to Friedman (2004) and Bates et al. (1973).

Plant growth analysis

Plant growth was estimated by measuring shoot height, root length and accumulation of root and shoot dry biomass (after drying the plant material at $70{ }^{\circ} \mathrm{C}$ for $72 \mathrm{~h}$ ).

\section{Statistical analysis}

Data were analyzed using SAS statistical software (version 9.3; SAS Institute 2012). An analysis of variance and means comparison using a Tukey test were applied with a significance level of $95 \%(P \leq 0.05)$ to determine statistical differences.

\section{Results}

\section{Primer specificity}

Primer specificity is a crucial factor for quantitative realtime PCR approaches. Therefore, all 57 NAC gene primer pairs were checked by qRT-PCR using cDNA synthesized from leaves of the rice cultivars Cotaxtla and Tres Ríos kept under control and salt stress conditions as described herein. Melting curve analyses were carried out for all PCR products to confirm the occurrence of specific amplification peaks and the absence of primer-dimer formation (data available upon request).

From the initial 57 NAC genes tested, 41 yielded detectable PCR amplicons, while the rest (16 genes) had aberrant expressions under our experimental conditions based on the dissociation curves, and so they were excluded after the analysis of the qRT-PCR data. All 41 primer pairs tested from this subset assay yielded unique PCR products of expected size from genomic DNA used as a template. Therefore, the expression data of poor quality (aberrant dissociation curves at low expression levels) from the 16 transcripts may indicate that these genes are expressed at extremely low levels or not at all under our experimental conditions (Czechowski et al. 2004). Similarly, Le et al. (2011) were able to find 42 gene-specific primers out of 58 primer pairs tested as a consequence of an even lower expression in the plant material used in that experiment.

Selection of reference genes

Actin (ACT), actin1 (ACT1), elongation factor $1 \alpha(E F 1 \alpha)$ and $\beta$-tubulin $(T U B)$ were tested to identify the most suitable reference genes for our rice cultivars and experimental conditions. The results are given in Table 1. ACT and $E F 1 \alpha$ displayed more stability and their expression was not significantly affected by salt treatments. $E F I \alpha$ was considered as a reference gene for further analysis, as this gene had the most stable expression with the lowest $M$ values.

Expression of $N A C$ genes in rice leaves with salt stress

Expression of $N A C$ genes is regulated by abiotic stress, including high salinity (Nakashima et al. 2012; Zhong et al. 2012). García-Morales et al. (2012) demonstrated that the cultivars Cotaxtla and Tres Ríos displayed contrasting physiological and biochemical responses to salt stress, with Cotaxtla more tolerant than Tres Ríos. To further examine the stress responses of such cultivars at the transcriptional level, plants were exposed to either 0 or $100 \mathrm{mM} \mathrm{NaCl}$ and expression of $N A C$ genes was monitored using qRT-PCR at different times. The gene OsNAC1O was included in the assay as a positive control, as it has been demonstrated to be induced by high salinity (Jeong et al. 2010). Three hours after treatment, the expressions of four $N A C$ genes were shown to be regulated by $\mathrm{NaCl}$ in Cotaxtla plants and that of 15 genes in Tres Ríos plants. Six hours after treatment, $\mathrm{NaCl}$ affected the expression of nine genes in Cotaxtla plants, whereas 15 genes were differentially expressed in Tres Ríos plants (Fig. 1; Table 2).

Different expression patterns were observed not only between cultivars (Cotaxtla and Tres Ríos) but also between time points ( 3 and $6 \mathrm{~h}$ after treatment) (Table 2). For instance, in Cotaxtla plants, genes Os06g46270, Os10g42130, Os06g51070, Os08g10080, Os02g36880 and Os04g38720 were up-regulated $3 \mathrm{~h}$ after treatment, whereas $6 \mathrm{~h}$ after exposure to $100 \mathrm{mM} \mathrm{NaCl}$ their expression was suppressed. In this rice cultivar, only two genes, OsO9g33490 and OsNAC6 exhibited an opposite response, as their expressions were up-regulated $3 \mathrm{~h}$ after treatment and down-regulated $6 \mathrm{~h}$ after exposure to salt stress (Table 2). As for Tres Ríos plants, 12 genes showed contrasting expression patterns between time points. Genes Os06g46270, Os03g03540, Os03g60080, Os06g51070, Missing annotation 2, Os10g21560, Os04g40130, Os08g10080, Os12g29330, Os02g36880, Os11g08210 and Os $05 \mathrm{~g} 34830$ were all down-regulated $3 \mathrm{~h}$ after treatment, but over-expressed $6 \mathrm{~h}$ after salt stress. All other genes were 
Table $1 \mathrm{C}_{\mathrm{T}}$ values of selected reference genes used to test the $N A C$ transcription factor gene expression in rice leaves upon osmotic stress

\section{Cotaxtla cultivar}
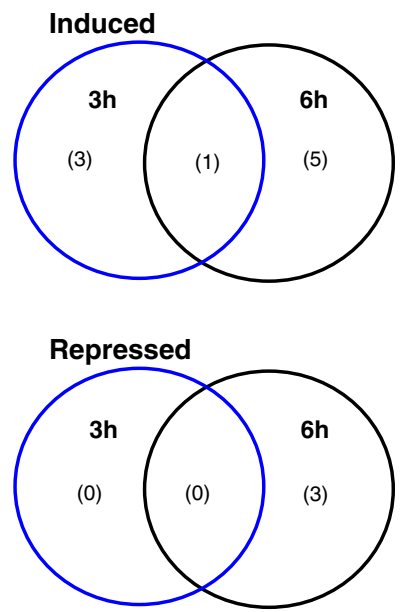

\begin{tabular}{|c|c|c|c|c|c|c|c|}
\hline \multirow{2}{*}{$\begin{array}{l}\text { Locus } \\
\text { identifier }\end{array}$} & \multirow[t]{2}{*}{ Gene name } & \multicolumn{5}{|l|}{$\mathrm{C}_{\mathrm{T}}$ Value } & \multirow{2}{*}{$\begin{array}{l}\text { Expression } \\
\text { stability }(M\end{array}$} \\
\hline & & Control_0 h & Control_3 h & $\mathrm{NaCl} \_3 \mathrm{~h}$ & Control_24 h & $\mathrm{NaCl} \_24 \mathrm{~h}$ & \\
\hline Os03g50890 & Actin & 19.9 & 17.4 & 17.2 & 20.9 & 20.7 & 0.17 \\
\hline Os05g36290 & Actin I & 16.0 & 21.8 & 19.8 & 21.0 & 21.7 & 0.18 \\
\hline Os03g08020 & $\begin{array}{r}\text { Elongation } \\
\text { factor }-1 \alpha\end{array}$ & 15.1 & 14.1 & 13.4 & 15.8 & 15.4 & 0.15 \\
\hline Os01g59150 & $\beta$-tubulin & 16.5 & 21.5 & 20.0 & 21.9 & 17.7 & 0.22 \\
\hline
\end{tabular}

Tres Ríos cultivar
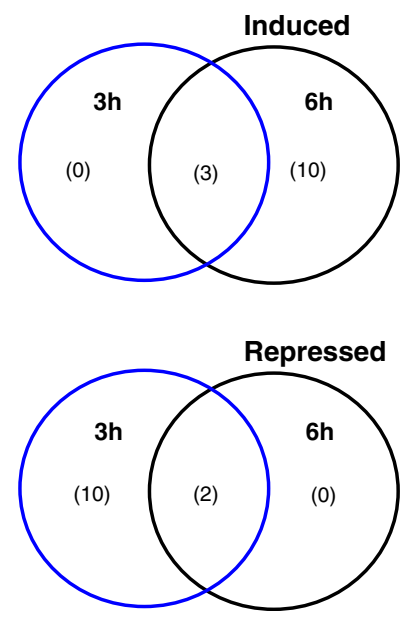

Fig. 1 Venn diagrams showing the number of $\mathrm{NaCl}$ stress-responsive $N A C$ genes in leaves from Cotaxtla and Tres Ríos rice plants. The $\mathrm{NaCl}$-regulated genes were defined as those genes whose expression was either induced (upper panel) or repressed (lower panel) with a cut-off value of twofold, 3 and $6 \mathrm{~h}$ after exposure to $100 \mathrm{mM} \mathrm{NaCl}$ treatment

consistently up- or down-regulated at the different time points measured. According to Nuruzzaman et al. (2013), a single $N A C$ gene often responds to several stress factors and their protein products may participate in the regulation of several seemingly disparate processes as negative or positive regulators. In addition, the NAC proteins function via auto-regulation and cross-regulation is extremely common among NAC genes. These observations assist in the understanding of the complex mechanisms of signaling and transcriptional reprogramming controlled by NAC proteins. Recent analyses indicate that a single NAC protein can regulate transcriptional reprogramming associated with different plant processes, while the dynamic web of signaling in which NAC factors operate has multiple inputs and outputs (Cenci et al. 2014; Nuruzzaman et al. 2013).

The positive control gene OsNAC1O was indeed induced in response to salt stress at both time points measured (3 and $6 \mathrm{~h}$ after treatment) in both elite cultivars. Interestingly, two NAC genes, OsO2g56600 and Os12g07790, were induced in Cotaxtla plants but repressed in Tres Ríos plants when exposed to $100 \mathrm{mM} \mathrm{NaCl}$ (Table 2). The gene
Os02g56600 encompasses three exons that result in a 996-bp transcript and a corresponding protein product of 331 amino acids. Instead, the gene $O s 12 \mathrm{~g} 07790$ is composed of only one exon of $1,716 \mathrm{bp}$, encoding a protein of 571 amino acid residues (Table 3 ).

Importantly, the protein products of the genes OsO2g56600 and Os $12 g 07790$ fall into two different phylogenetic clusters, according to their motif organization (Fang et al. 2008; Nuruzzaman et al. 2010). Indeed, analysis of their corresponding promoter regions for the presence of potential cis regulatory elements using the PLACE (www. dna.affrc.go.jp/htdocs/PLACE/fasta.html) and PlantCARE (intra.psb.ugent.be:8080/PlantCARE) interfaces revealed cis elements that may contribute to salt-responsive gene expression (data available upon request). Elevated expression of $0 s 02 g 56600$ in roots and shoots was also evident from Affymetrix GeneChip hybridization data (A-AFFY126) that were retrieved using the Expression Atlas tool of the EMBL-EBI platform (http://www.ebi.ac.uk/gxa/gene/ LOC_Os02g56600), although no data on stress treatments were retrieved. In spite of the fact that no expression data of Os $12 g 07790$ could be retrieved from GenBank ${ }^{\mathrm{TM}}$ or Affymetrix GeneChip, it is evident from Nuruzzaman et al. (2010) expression profiling findings that this gene is indeed expressed and induced by stress, which is in agreement with our results. Although phylogenetic analyses provide important bioinformatics support for candidate gene selection, we are aware that it alone cannot clearly indicate a precise biological function. Therefore, our expression profiling analysis at the level of mRNA transcript represents a good approach for future investigation to further understand the structure and function of candidate NAC TF selected so far and provides a new avenue for their functional analyses in rice.

Amino acid and proline concentrations

Total free amino acid concentrations increased with salt stress in both cultivars, although Cotaxtla plants showed a higher concentration in comparison to Tres Ríos plants (Fig. 2a). Interestingly, Cotaxtla plants displayed a 16-fold increase in proline concentration in comparison to control plants (i.e., 0.17 versus $2.80 \mu \mathrm{mol} \mathrm{g}^{-1} \mathrm{FW}$, respectively), 
Table 2 Expression level of $N A C$ genes in leaves from Cotaxtla and Tres Ríos rice plants under $\mathrm{NaCl}$ stress
Samples were taken 3 and $6 \mathrm{~h}$ after treatment. Gene expression was quantified using the comparative methods CT (threshold cycle): $2^{-\Delta \Delta C T}$, where $\Delta \Delta \mathrm{CT}$ represents

$\Delta \mathrm{CT}_{\text {condition of interest }}-$

$\Delta \mathrm{CT}_{\text {control }}$ Elongation factor $1 \alpha$ was used as a reference gene for data normalization. Fold change highlighted in bold shows genes were either up-regulated by at least twofold or down-regulated at least twofold by $\mathrm{NaCl}$ stress

$M A$ missing annotation

Means (two biological replicates) with different letters in each row are significantly different (Tukey, $P \leq 0.05)$

\begin{tabular}{|c|c|c|c|c|c|}
\hline \multirow[t]{3}{*}{ Identification TIGR v5.0 } & \multirow[t]{3}{*}{ Annotation } & \multicolumn{4}{|c|}{ Relative expression (fold change) } \\
\hline & & \multicolumn{2}{|l|}{ Cotaxtla } & \multicolumn{2}{|l|}{ Tres Ríos } \\
\hline & & $3 \mathrm{~h}$ & $6 \mathrm{~h}$ & $3 \mathrm{~h}$ & $6 \mathrm{~h}$ \\
\hline Os06g46270 & NAC domain protein NAC1 & $1.36 \mathrm{a}$ & $-1.40 \mathrm{~b}$ & $-2.00 \mathrm{~b}$ & $1.50 \mathrm{a}$ \\
\hline Os02g56600 & $\begin{array}{l}\text { No apical meristem (NAM) } \\
\text { protein, putative }\end{array}$ & $1.75 \mathrm{a}$ & $2.03 \mathrm{a}$ & $-2.29 \mathrm{~b}$ & $-1.51 \mathrm{~b}$ \\
\hline Os03g03540 & $\begin{array}{l}\text { No apical meristem (NAM) } \\
\text { protein, putative }\end{array}$ & $1.84 \mathrm{a}$ & $1.54 \mathrm{a}$ & $-2.94 \mathrm{~b}$ & $1.18 \mathrm{a}$ \\
\hline Os08g33910 & $\begin{array}{l}\text { Similar to NAM (no apical } \\
\text { meristem)-like protein }\end{array}$ & $1.28 \mathrm{~b}$ & $1.38 \mathrm{~b}$ & $1.32 \mathrm{~b}$ & $2.62 \mathrm{a}$ \\
\hline Os03g60080 & $\begin{array}{l}\text { Putative NAC domain } \\
\text { protein }\end{array}$ & $-1.22 b$ & $-1.59 \mathrm{~b}$ & $-1.93 b$ & $2.45 \mathrm{a}$ \\
\hline Os $10 g 42130$ & $\begin{array}{l}\text { Putative NAM (no apical } \\
\text { meristem) protein }\end{array}$ & $1.87 \mathrm{a}$ & $-2.41 \mathrm{~b}$ & $-2.40 \mathrm{~b}$ & $-2.15 b$ \\
\hline Os07g04560 & Hypothetical protein & $-1.9 \mathrm{a}$ & $-7.49 \mathrm{c}$ & $-13.01 \mathrm{~d}$ & $-5.62 b$ \\
\hline Os06g51070 & $\begin{array}{l}\text { NAM (no apical meristem)- } \\
\text { like protein [imported]- } \\
\text { Arabidopsis thaliana }\end{array}$ & $1.40 \mathrm{a}$ & $-1.69 \mathrm{~b}$ & $-2.07 \mathrm{~b}$ & $2.27 \mathrm{a}$ \\
\hline Os09g33490 & $\begin{array}{l}\text { Similar to NAC domain } \\
\text { protein NAC2 }\end{array}$ & $-1.39 \mathrm{~b}$ & $1.18 \mathrm{ab}$ & $2.01 \mathrm{a}$ & $2.19 \mathrm{a}$ \\
\hline Os02g34970 & Hypothetical protein & $1.51 \mathrm{~b}$ & $6.26 \mathrm{a}$ & $1.32 \mathrm{~b}$ & $1.70 \mathrm{~b}$ \\
\hline$M A \_2$ & $\begin{array}{l}\text { No apical meristem (NAM) } \\
\text { protein, putative }\end{array}$ & $2.14 \mathrm{a}$ & $1.24 \mathrm{a}$ & $-2.24 b$ & $1.74 \mathrm{a}$ \\
\hline Os $10 g 21560$ & Putative transcription factor & $-1.31 \mathrm{~b}$ & $-1.21 \mathrm{~b}$ & $-1.69 \mathrm{~b}$ & $2.06 \mathrm{a}$ \\
\hline Os12g07790 & Hypothetical protein & $1.53 \mathrm{a}$ & $2.16 \mathrm{a}$ & $-2.22 b$ & $-1.61 \mathrm{~b}$ \\
\hline Os04g40130 & $\begin{array}{l}\text { Similar to probable salt- } \\
\text { inducible protein } \\
\text { [imported]-Arabidopsis } \\
\text { thaliana }\end{array}$ & $1.15 \mathrm{a}$ & $1.67 \mathrm{a}$ & $-1.71 \mathrm{~b}$ & $2.32 \mathrm{a}$ \\
\hline Os08g 10080 & $\begin{array}{l}\text { Similar to NAC domain } \\
\text { protein NAC1 }\end{array}$ & $1.59 \mathrm{a}$ & $-2.38 \mathrm{~b}$ & $-1.13 b$ & $1.74 \mathrm{a}$ \\
\hline Os12g29330 & $\begin{array}{l}\text { Similar to NAC domain } \\
\text { protein NAC2 }\end{array}$ & $1.53 \mathrm{a}$ & $1.23 \mathrm{a}$ & $-1.82 \mathrm{~b}$ & $2.23 \mathrm{a}$ \\
\hline Os02g36880 & OsNAC1 protein & $2.38 \mathrm{a}$ & $-1.95 \mathrm{~b}$ & $-3.97 c$ & $2.13 \mathrm{a}$ \\
\hline Os04g38720 & OsNAC2 protein & $2.13 \mathrm{a}$ & $-1.47 \mathrm{ab}$ & $-3.44 b$ & $-1.58 \mathrm{ab}$ \\
\hline Os11g08210 & $\begin{array}{l}\text { OsNAC5 protein } \\
\text { [imported]—rice }\end{array}$ & $1.88 \mathrm{a}$ & $3.32 \mathrm{a}$ & $-4.01 \mathrm{~b}$ & $2.14 \mathrm{a}$ \\
\hline Os05g34830 & $\begin{array}{l}\text { OsNAC5 protein } \\
\text { [imported]—rice }\end{array}$ & $1.70 \mathrm{a}$ & $2.68 \mathrm{a}$ & $-3.1 b$ & $2.06 \mathrm{a}$ \\
\hline OsNAC5 & OsNAC5 & $1.04 \mathrm{a}$ & $1.24 \mathrm{a}$ & $1.89 \mathrm{a}$ & $2.13 \mathrm{a}$ \\
\hline OsNAC6 & OsNAC6 & $-1.83 \mathrm{c}$ & $1.72 \mathrm{~b}$ & $2.60 \mathrm{~b}$ & $7.93 \mathrm{a}$ \\
\hline OsNAC10 & OsNAC10 & $2.49 \mathrm{~b}$ & $2.60 \mathrm{~b}$ & 8.09 a & $4.63 \mathrm{~b}$ \\
\hline
\end{tabular}

while in Tres Ríos plants proline concentrations reached only a fivefold increase in treated plants in comparison to controls (i.e., 0.12 versus $0.63 \mu \mathrm{mol} \mathrm{g}{ }^{-1} \mathrm{FW}$, respectively) (Fig. 2b).

Plant growth and biomass accumulation

Shoot height was affected by salt stress in both cultivars (Fig. 3a). In other rice cultivars such as Bomba and Bahia, plants treated with $150 \mathrm{mM} \mathrm{NaCl}$ showed a $75 \%$ growth reduction in comparison to control plants (Wankhade et al. 2013). Concerning root length, no significant effects of treatments were detected in either cultivar (Fig. 3b). One of the initial effects of salt stress on plants is the reduction of growth rate and restriction of leaf growth as among the earliest visible effects of such stress. Because leaves determine radiation interception and are the main photosynthetic structures, salinity effects on leaf expansion and function are directly related to yield constraints under saline conditions (Wankhade et al. 2013). The mechanisms by which salinity affects plant growth depend on the time scale over which the plant is exposed to salt. Munns (2005) developed the 'two-phase' growth response to salt stress. The first phase of growth reduction is a rapid process due to 
Table 3 Annotation update of the genes $O s 02 g 56600$ and $O s 12 g 07790$, that showed contrasting expression profiling in leaves of the cultivars Cotaxtla (salt tolerant) and Tres Ríos (salt sensitive) treated with $\mathrm{NaCl}$

\begin{tabular}{llllll}
\hline Sequence ID & Transcript length (bp) & Protein length (aa) & Number of exons & Phylogenetic group $^{\mathrm{a}}$ & MEME group $^{\mathrm{b}}$ \\
\hline Os02g56600 & 996 & 331 & 3 & NAC22 & A \\
Os12g07790 & 1,716 & 571 & 1 & OSNAC3 & K \\
\hline
\end{tabular}

Sequence ID was adopted from TIGR, according to Fang et al. (2008) and Nuruzzaman et al. (2010)

$A$ proteins containing five highly conserved N-terminal DNA-binding domains, $K$ proteins harboring four conserved N-terminal DNA-binding domains

${ }^{\text {a }}$ Phylogenetic groups are as reported by Nuruzzaman et al. (2010)

b MEME groups are as described by Fang et al. (2008)

Fig. 2 Concentration of total amino acids (a) and proline (b) in leaves of Cotaxtla and Tres Ríos rice cultivars under $\mathrm{NaCl}$ treatment. Samples were taken 15 days after treatment. Bars are means of four biological replicates. Means \pm SD with different letters in each column are significantly different (Tukey, $P \leq 0.05)$
A

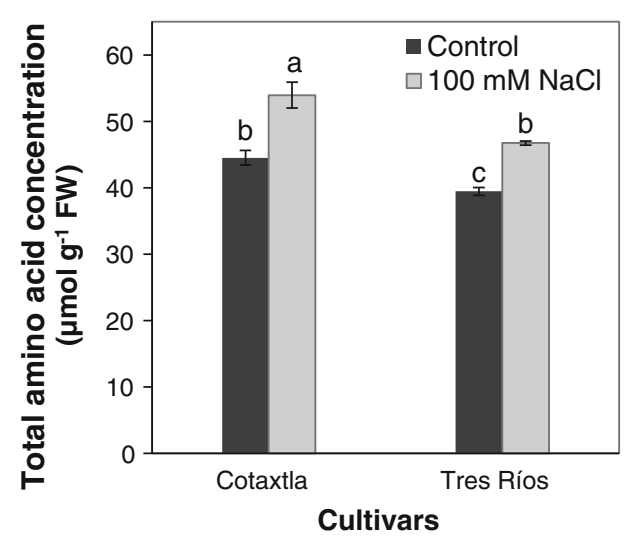

A

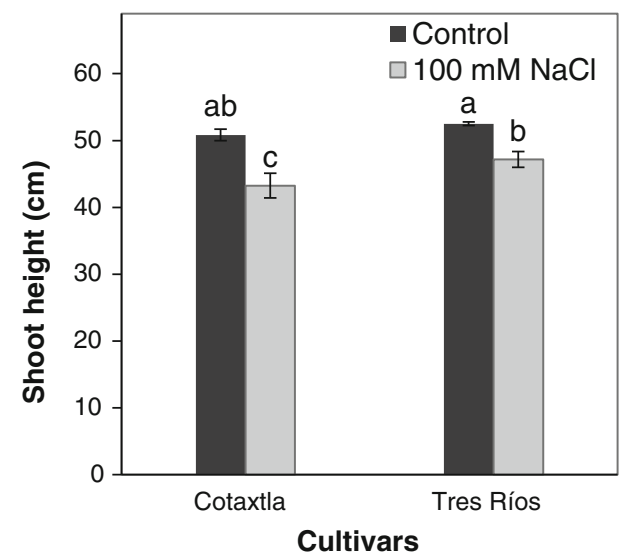

\section{Cultivars}

B

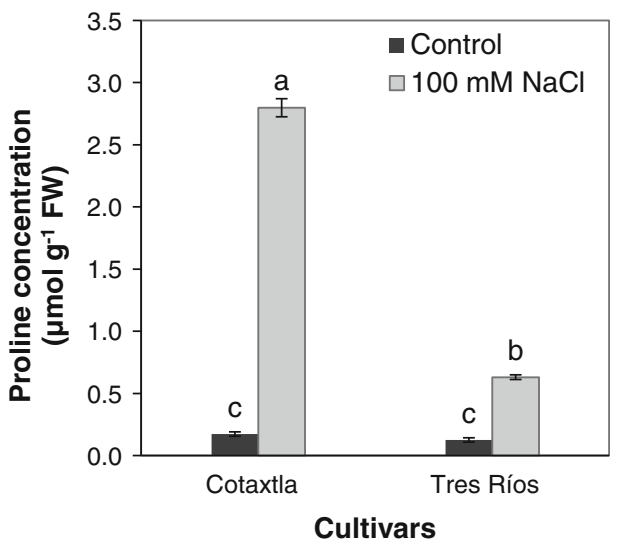

B

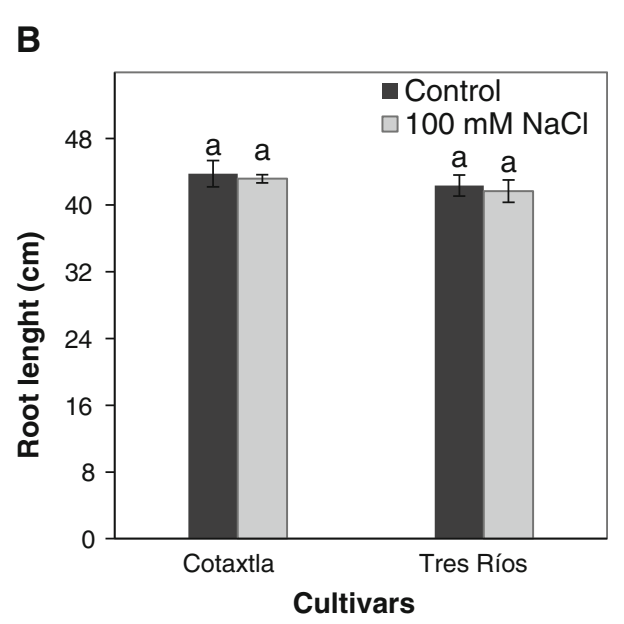

Fig. 3 Growth analyses of Cotaxtla and Tres Ríos rice plants under $\mathrm{NaCl}$ treatment. a Shoot height and $\mathbf{b}$ root length 15 days after treatment. Bars are means of six biological replicates. Means \pm SD with different letters in each column are significantly different

(Tukey, $P \leq 0.05$ ) osmosis. The second phase is a slower process due to salt accumulation in leaves, leading to salt toxicity in the plants. The latter can result in death of leaves and reduce the total photosynthetic leaf area which in turn decreases the supply of photosynthates in plants and ultimately affects yield (Hasanuzzaman et al. 2013; Munns 2002; Munns and Tester 2008).

As a consequence of salt stress in plants, dry weight was drastically reduced, which yielded an increase in the root to shoot ratio for Cotaxtla plants, while in Tres Ríos plants a significant reduction in this ratio was observed (Fig. 4). In most crop species, shoot growth is more sensitive to salt than root growth (Bernstein and Kafkafi 2002) and the root to shoot ratio therefore typically increases under salinity (Bernstein et al. 2004). In our study, salt stress caused more drastic effects on shoot than in root biomass, and thus a higher root to shoot ratio was observed in salt-treated plants in comparison to control plants. 
Fig. 4 Root to shoot ratios for Cotaxtla and Tres Ríos rice plants under $\mathrm{NaCl}$ treatment. a Ratios for fresh weight (FW). b Ratios for dry weight (DW). Bars are means of six biological replicates. Means \pm SD with different letters in each column are significantly different

(Tukey, $P \leq 0.05$ )
A

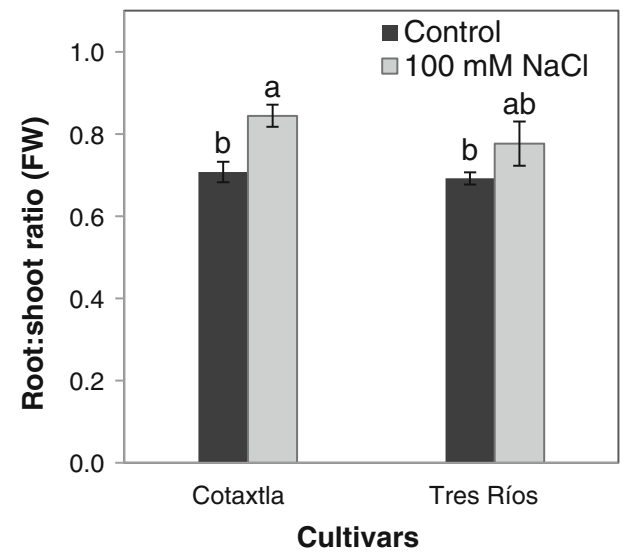

B

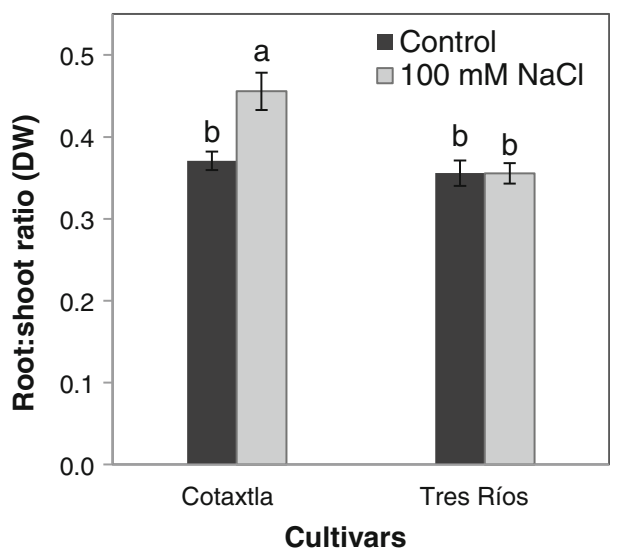

\section{Discussion}

Similarities and differences between our results and those obtained by other research groups have been observed. For instance, Nuruzzaman et al. (2010) reported that the gene Oslog42130 showed no significant changes when exposed to $150 \mathrm{mM} \mathrm{NaCl}$. In our experiment, this gene showed no changes $3 \mathrm{~h}$ after treatment of Cotaxtla plants, although in Tres Ríos plants it was down-regulated; interestingly, its expression remained down-regulated in both cultivars $6 \mathrm{~h}$ after treatment. Furthermore, the gene $0 s 01 \mathrm{~g} 15640$ was found to be non-responsive to $\mathrm{NaCl}$ according to Nuruzzaman et al. (2010), which is in agreement with our results. We previously reported that the Cotaxtla cultivar maintained $10 \%$ of the photosynthetic activity 6 days after applying $100 \mathrm{mM} \mathrm{NaCl}$ to the nutrient solution, while Tres Ríos plants had no photosynthetic activity after such treatment. Similarly, salt treatment reduced shoot and root growth by 20 and $15 \%$ compared to the control plants in Tres Ríos, respectively, whereas in Cotaxtla this reduction was approximately $6 \%$ in both cases (García-Morales et al. 2012). We do not rule out the possibility that such discrepancies may have been in part due to the different genetic backgrounds of the rice cultivars evaluated as reflected at the biochemical, physiological and molecular levels. For instance, the core motif of DRECRTCOREAT cis-acting element (consensus sequence RCCGAC) found in both $N A C$ gene promoter regions has been reported to be present in many high-salt-responsive genes in rice and sunflower (Helianthus annuus) (Díaz-Martín et al. 2005). Moreover, other physiological and biochemical responses described herein or by García-Morales et al. (2012), including distinct strategies for nutrient uptake and accumulation of total amino acids and proline, help to explain the different salt stress tolerance levels of our cultivars. When comparing our results to those reported by Nuruzzaman et al. (2010), differences may be due to the level of stress tested (i.e., 100 versus $150 \mathrm{mM} \mathrm{NaCl}$ ), plant growth phase (10-day-old seedlings versus 34-day-old plants) and the genetic material evaluated. Importantly, our results confirm that $N A C$ genes are differentially regulated upon salt stress treatment and variations between cultivars are known. Likewise, complex post-transcriptional regulation involving microRNA (miRNA)-mediated cleavage of genes may take place as well (Puranik et al. 2012), making individual characterization of $N A C$ genes a daunting task. These small RNA molecules (miRNAs) are trans-factors that regulate gene expression at both the transcript and the protein level, and at their downstream target genes, controlling processes related to development, metabolism and stress responses (Chiou et al. 2006; Zhang et al. 2006). Interestingly, the promoter region of the gene $O s 2 g 56600$ has 25 miRNA target sites (of nine different types), while that of the gene Os12g07790 has 14 sites (of five types). Therefore, there is a dire need to understand the exact regulatory mechanisms of all stress-responsive NAC genes. Thus, we are currently further investigating $N A C$ gene transcriptional regulation and screening for insertional mutants from rice T-DNA tagging pools.

Under salt stress conditions, tolerant crops display an enhanced accumulation of amino acids, but little or no amino acid accumulation occurs in salt sensitive crops (Sobhanian et al. 2011; Chang et al. 2014). Specifically, amino acid metabolism plays a central role in the response to salt stress in species of the Poaceae family (Hameed et al. 2013). In our study, both cultivars increased their amino acid content when exposed to salt tress, although this increase was higher in Cotaxtla plants (salt tolerant) in comparison to Tres Ríos (salt sensitive). Moreover, proline concentration was almost fivefold higher in Cotaxtla plants exposed to $\mathrm{NaCl}$ as compared to Tres Ríos plants under salt stress. Proline and free amino acids act as compatible solutes to protect cellular macromolecules, maintain osmotic balance and also scavenge the free radicals 
produced under salt stress conditions (Sneha et al. 2013). Manipulating amino acid metabolism may be a promising approach of improving salt tolerance of cereal crops and therefore, Cotaxtla appears to represent an excellent model cultivar to further investigate mechanisms of salt tolerance with respect to amino acids.

Mechanisms of salt tolerance can be explained to some extent by stress adaptation effectors that mediate ion homeostasis, osmolyte biosynthesis, toxic radical scavenging, water transport and long distance response coordination (Hasanuzzaman et al. 2013; Hasegawa et al. 2000). In recent decades, osmoprotectants such as proline, glycine betaine and trehalose have been found effective in mitigating salt-induced damage in plants (Ahmed et al. 2010). These protectants showed the capacity to enhance plant growth, yield and stress tolerance when exposed to salinity. In particular, proline accumulation is a wellknown adaptive mechanism in plants against salt stress conditions, and this mechanism can serve as a selection criterion for the tolerance of most species to stressful conditions (Hasanuzzaman et al. 2013; Hayat et al. 2012). Our results are comparable to those reported by Moradi and Ismail (2007) in rice cultivars IR29 (salt sensitive) and IR651 (salt tolerant). According to García-Morales et al. (2012), Cotaxtla plants were more tolerant to salt stress in comparison to Tres Ríos plants, a response that corresponds with the highest concentration of proline observed in Cotaxtla plants. The role of proline as a compatible osmolyte and osmoprotectant during salt stress is as an antioxidant, suggesting an ROS scavenging activity (Matysik et al. 2002; Smirnoff and Cumbes 1989). Proline also induces the expression of salt stress-responsive proteins, may serve as a signaling molecule (Khedr et al. 2003; Hoque et al. 2008; Szabados and Svouré 2009) and protects higher plants against osmotic stresses not only by adjusting osmotic pressure, but also by stabilizing functional units such as complex II electron transport, membranes, proteins and enzymes such as RuBisCo (Hamilton and Heckathorn 2001) as well as the photosynthetic apparatus (Ashraf and Foolad 2007). Sobahan et al. (2009) further reported that exogenous proline suppressed $\mathrm{Na}^{+}$-enhanced apoplastic flow to reduce sodium uptake in rice plants, while the transcription of genes encoding several antioxidant enzymes is up-regulated in the presence of proline (Nounjan et al. 2012).

Concerning root to shoot ratios, Momayezi et al. (2012) observed that the Fajr rice genotype (salt tolerant) had the highest values for agronomic parameters including root characteristics, root to shoot ratio, dry biomass and water content of roots, in comparison to the Khazar genotype (salt sensitive), and these results are similar to our findings reported herein. Furthermore, Zhang et al. (2012) also demonstrated that the salt tolerant rice genotype IR651 showed a root to shoot ratio significantly higher than that of IR64, a moderately tolerant genotype, when plants were exposed to a $\mathrm{CE}$ of $9.8 \mathrm{dS} \mathrm{m} \mathrm{m}^{-1}$ in the soil. Both findings are in agreement with our results, as the salt tolerant cultivar Cotaxtla performed better under salt stress, including producing a higher root to shoot ratio. These results indicate that while shoot growth was inhibited by salt treatment, root growth continued or was not inhibited. According to Albacete et al. (2008), the increase in the root to shoot ratio is a crucial characteristic of adaptation to salt stress in plant species, as shown herein by Cotaxtla plants.

In the light of the findings in this study, we conclude that elite rice cultivars grown under salinity exhibited differential expression of $N A C$ genes, amino acids and proline content, as well as growth compared to control plants. In comparison to Tres Ríos, the Cotaxtla cultivar showed better performance when exposed to salt stress, as it accumulated more free amino acids and proline, and the root to shoot ratio for Cotaxtla plants was higher in comparison to that observed in Tres Ríos plants treated with salt. At the molecular level, 23 NAC genes showed regulation by $\mathrm{NaCl}$, among which $0 s 02 g 56600$ and Os12g07790 are induced in Cotaxtla plants, but repressed in Tres Ríos plants. Further studies using a large and more diverse set of rice genotypes, time points and developmental stages of plants are needed to evaluate the potential use of these parameters in breeding for salt tolerance in rice cultivars. Considering that a very limited number of $N A C$ genes have been characterized so far, the identification of $\mathrm{NaCl}$ responsiveness of $N A C$ transcription factors that we provide herein represents a very useful reference for functional analysis of this family in rice. Therefore, this study has provided not only a cultivar-specific expression profiling of NAC genes, but also some biochemical responses underlying the differential mechanisms of two elite rice cultivars exhibiting contrasting tolerance levels to salt stress. These data provide a very useful reference as well as a starting point for revealing the functions of NAC genes, especially for those involved in the regulation of $\mathrm{NaCl}$ stress responses.

Author contribution Dr. Fernando C. Gómez-Merino designed and supervised the experiments and wrote the paper. Dr. Soledad García-Morales performed the greenhouse and laboratory experiments, data collection and analysis. Dr. Libia I. Trejo-Téllez established the hydroponic culture and helped in manuscript discussion and editing.

Acknowledgments This research was supported by a grant from the National Council of Science and Technology (CONACyT) from Mexico to SGM. We thank the Priority Research Line 5 Biotechnology from the Colegio de Postgraduados-Mexico for providing laboratory and other research facilities. We are very grateful to Prof. 
Bernd Mueller-Roeber and to Dr. Camila Caldana for their initial support establishing the qRT-PCR platform described herein.

Conflict of interest The authors declare that they have no conflicts of interest.

Open Access This article is distributed under the terms of the Creative Commons Attribution License which permits any use, distribution, and reproduction in any medium, provided the original author(s) and the source are credited.

\section{References}

Ahmed CB, Rouina BB, Sensoy S, Boukhriss M, Abdullah FB (2010) Exogenous proline effects on photosynthetic performance and antioxidant defense system of young olive tree. J Agric Food Chem 58:4216-4222

Albacete A, Ghanem ME, Martínez-Andújar C, Acosta M, SánchezBravo J, Martínez V, Lutts S, Dodd IC, Pérez-Alfocea F (2008) Hormonal changes in relation to biomass partitioning and shoot growth impairment in salized tomato (Solanum lycopersicum L.) plants. J Exp Bot 69:4118-4131

Ashraf M, Foolad MR (2007) Roles of glycine betaine and proline in improving plant abiotic stress resistance. Environ Exp Bot 59:206-216

Bates LS, Waldren RP, Teare ID (1973) Rapid determination of free proline for water stress studies. Plant Soil 39:2005-2007

Bernstein N, Kafkafi U (2002) Root growth under salinity stress. In: Weisel Y, Eshel A, Kafkafi U (eds) Plant root: the hidden half. Marcel Dekker, New York, pp 787-819

Bernstein N, Meiri A, Zilberstaine M (2004) Root growth of avocado is more sensitive to salinity than shoot growth. J Amer Hort Sci 129:188-192

Caldana C, Scheible WR, Mueller-Roeber B, Ruzicic S (2007) A quantitative RT-PCR platform for high-throughput expression profiling of 2500 rice transcription factors. Plant Meth 3(7). doi:10.1186/1746-4811-3-7

Cenci A, Guignon V, Roux N, Rouard M (2014) Genomic analysis of NAC transcription factors in banana (Musa acuminata) and definition of NAC orthologous groups for monocots and dicots. Plant Mol Biol 85(1-2):63-80. doi:10.1007/s11103-013-0169-2

Chang B, Yang L, Cong W, Zu Y, Tang Z (2014) The improved resistance to high salinity induced by trehalose is associated with ionic regulation and osmotic adjustment in Catharanthus roseus. Plant Physiol Biochem 77C:140-148. doi:10.1016/j.plaphy. 2014.02.001

Chen X, Wang Y, Lv B, Li J, Luo L, Lu S, Zhang X, Ma H, Ming F (2014) The NAC family of transcription factor OSNAP confers abiotic stress response through the ABA pathway. Plant Cell Physiol. doi:10.1093/pcp/pct2014

Chiou TJ, Aung K, Lin SI, Wu CC, Chiang SF, Su CL (2006) Regulation of phosphate homeostasis by microRNA in Arabidopsis. Plant Cell 18:412-421

Czechowski T, Bari RP, Stitt M, Scheible WR, Udvardi M (2004) Real-time RT-PCR profiling of over 1400 Arabidopsis transcription factors: unprecedented sensitivity reveals novel rootand shoot-specific genes. Plant J 38:366-379

Díaz-Martín J, Almoguera C, Prieto-Dapena P, Espinosa JM, Jordano $\mathrm{J}$ (2005) Functional interaction between two transcription factors involved in the developmental regulation of a small heat stress protein gene promoter. Plant Physiol 139:1483-1494

Fang J, You J, Xie K, Xie W, Xiong L (2008) Systematic sequence analysis and identification of tissue-specific or stress-responsive genes of NAC transcription factor family in rice. Mol Genet Genomics 280:547-563. doi:10.1007/s00438-008-0386-6

Friedman M (2004) Applications of the ninhydrin reaction for analysis of amino acids, peptides, and proteins to agricultural biomedical sciences. J Amer Food Chem 52:385-406

García-Morales S, Trejo-Téllez LI, Gómez-Merino FC, Caldana C, Espinosa-Victoria D, Herrera-Cabrera E (2012) Growth, photosynthetic activity and potassium and sodium concentration in rice plants under salt stress. Acta Sci 34:317-324

Hameed M, Nawaz T, Ashraf M, Naz N, Batool R, Sajid M, Ahmad A, Riaz A (2013) Physioanatomical adaptations in response to salt stress in Sporobolus arabicus (Poaceae) from the Salt Range, Pakistan. Turk J Bot 37:715-724. doi:10.3906/bot-1208-1

Hamilton EW, Heckathorn SA (2001) Mitochondrial adaptation to $\mathrm{NaCl}$. Complex I is protected by antioxidants and small heat shock proteins, whereas complex II is protected by proline and betaine. Plant Physiol 126:1266-1274

Hasanuzzaman M, Nahar K, Fujita M (2013) Plant response to salt stress and role of exogenous protectants to mitigate salt-induced damages. In: Ahmad P, Azooz MN, Prasad MNV (eds) Ecophysiology and responses of plant under salt stress. Springer, New York, pp 25-87

Hasegawa P, Bressan RA, Zhu JK, Bohnert HJ (2000) Plant cellular and molecular responses to high salinity. Annu Rev Plant Physiol Plant Mol Biol 51:463-499

Hayat S, Hayat Q, Alyemeni MN, Wani AS, Pichtel J, Ahmad A (2012) Role of proline under changing environments: a review. Plant Signal Behav 7:1-11

Hoque MA, Okuma E, Nakamara Y, Shimoishi Y, Murata Y (2008) Proline and glycine betaine enhance antioxidant defense and methylglyoxal detoxification systems and reduce $\mathrm{NaCl}$ induced damage in cultured tobacco cells. J Plant Physiol 165:813-824

$\mathrm{Hu}$ H, Dai M, Yao J, Xiao B, Li X, Zhang Q, Xiong L (2006) Overexpressing a NAM, ATAF, and CUC (NAC) transcription factor enhances drought resistance and salt tolerance in rice. Proc Nat Acad Sci USA 103:12987-12992. doi:10.1073/pnas. 0604882103

Jeong JS, Kim YS, Baek KH, Jung H, Ha SH, Choi YD, Kim M, Reuzeau C, Kim JK (2010) Root-specific expression of OsNAC10 improves drought tolerance and grain yield in rice under field drought conditions. Plant Physiol 153:185-197

Khedr AHA, Abbas MA, Wahid AAA, Quick WP, Abogadallah GM (2003) Proline induces the expression of salt-stress-responsive proteins and may improve the adaptation of Pancratium maritimum L. to salt-stress. J Exp Bot 54:2553-2562

Le DT, Nishiyama R, Watanabe Y, Mochida K, YamaguchiShinozaki K, Shinozaki K, Tran LSP (2011) Genome-wide survey and expression analysis of the plant-specific NAC transcription factor family in soybean during development and dehydration stress. DNA Res 18:263-276

Liu G, Li X, Jin S, Liu X, Zhu L, Nie X, Zhang X (2014) Overexpression of rice NAC gene SNACl improves drought and salt tolerance by enhancing root development and reducing transpiration rate in transgenic cotton. PLoS One 9(1):e86895. doi:10.1371/journal.pone.0086895

Mao X, Zhang H, Qian X, Li A, Zhao G, Jing R (2012) TaNAC2, a NAC-type wheat transcription factor conferring enhanced multiple abiotic stress tolerances in Arabidopsis. J Exp Bot 63:2933-2946

Mao X, Chen S, Li A, Zhai C, Jing R (2014) Novel NAC transcription factor TaNAC67 confers enhanced multi-abiotic stress tolerance in Arabidopsis. PLoS One 9(1):e84359. doi:10.1371/journal. pone. 0084359

Matysik J, Alia, Bhalu B, Mohanty P (2002) Molecular mechanisms of quenching of reactive oxygen species by proline under stress in plants. Curr Sci 82:525-532 
Momayezi MR, Zaharah AR, Hanafi MM (2012) The effects of cation ratios on root lamella suberization in rice (Oryza sativa L.) with contrasting salt tolerance. Int J Agron. doi:10.1155/2012/76919

Moradi F, Ismail AM (2007) Responses of photosynthesis, chlorophyll fluorescence and ROS-scavenging systems to salt stress during seedling and reproductive stages in rice. Ann Bot 99:1161-1173

Munns R (2002) Salinity, growth and phytohormones. In: Lauchli A, Luttge U (eds) Salinity: environment-plants-molecules. Kluwer, Dordrecht, pp 271-290

Munns R (2005) Genes and salt tolerance: bringing them together. New Phytol 167:645-663

Munns R, Tester M (2008) Mechanisms of salinity tolerance. Annu Rev Plant Biol 59:651-681

Nakashima K, Tran LS, Van Nguyen D, Fujita M, Maruyama K, Todaka D, Ito Y, Hayashi N, Shinozaki K, YamaguchiShinozaki K (2007) Functional analysis of a NAC-type transcription factor OsNAC6 involved in abiotic and biotic stressresponsive gene expression in rice. Plant J 51:617-630

Nakashima K, Takasaki H, Mizoi J, Shinozaki K, YamaguchiShinozaki K (2012) NAC transcription factors in plant abiotic stress responses. Biochim Biophys Acta 1819:97-103

Nounjan N, Nghia PT, Theerakulpisut P (2012) Exogenous proline and trehalose promote recovery of rice seedlings from salt-stress and differentially modulate antioxidant enzymes and expression of related genes. J Plant Physiol 169:59-604

Nuruzzaman M, Manimekalai R, Sharoni AM, Satoh K, Kondoh H, Ooka H, Kikuchi S (2010) Genome-wide analysis of NAC transcription factor family in rice. Gene 465:30-44

Nuruzzaman M, Sharoni AM, Kikuchi S (2013) Roles of NAC transcription factors in the regulation of biotic and abiotic stress responses in plants. Front Microbiol 4:248. doi:10.3389/fmicb. 2013.00248

Puranik S, Sahu PP, Srivastava PS, Prasad M (2012) NAC proteins: regulation and role in stress tolerance. Trend Plant Sci 17:369-381

Ramegowda V, Senthil-Kumar M, Nataraja KN, Reddy MK, Mysore KS, Udayakumar M (2012) Expression of a finger millet transcription factor, EcNAC1, in tobacco confers abiotic stresstolerance. PLoS One 7:e40397. doi:10.1371/journal.pone. 0040397

Saad AS, Li X, Li HP, Huang T, Gao CS, Guo MW, Cheng W, Zhao GY, Liao YC (2013) A rice stress-responsive NAC gene enhances tolerance of transgenic wheat to drought and salt stresses. Plant Sci 203-204:33-40. doi:10.1016/j.plantsci.2012. 12.016

SAS (2012) SAS/STAT ${ }^{\circledR} 9.3$ User's Guide. SAS Institute. Cary, NC, USA
Smirnoff N, Cumbes QJ (1989) Hydroxyl radical scavenging activity of compatible solutes. Phytochem 28:1057-1060

Sneha S, Rishi A, Dadhich A, Chandra S (2013) Effect of salinity on seed germination, accumulation of proline and free amino acids in Pennisetum glaucum (L.) R. Br. Pak J Biol Sci 16:877-881

Sobahan MA, Arias CR, Okuma E, Shimoishi Y, Nakamura Y, Hirai Y, Mori IC, Murata Y (2009) Exogenousproline and glycinebetaine suppress apoplastic flow to reduce $\mathrm{Na}^{+}$uptake in rice seedlings. Biosci Biotechnol Biochem 73:2037-2042

Sobhanian H, Aghaei K, Komatsu S (2011) Changes in the plant proteome resulting from salt stress: toward the creation of salttolerant crops? J Proteomics 74:1323-1337

Sperotto RA, Ricachenevsky FK, Duarte GL, Boff T, Lopes KL, Sperb ER, Grusak MA, Fett JP (2009) Identification of upregulated genes in flag leaves during rice grain filling and characterization of $O s \mathrm{NAC} 5$, a new ABA-dependent transcription factor. Planta 230:985-1002. doi:10.1007/s00425-0091000-9

Szabados L, Svouré A (2009) Proline: a multifunctional amino acid. Trends Plant Sci 15:89-97

Tran LSP, Nakashima K, Sakuma Y, Simpson SD, Fujita Y et al (2004) Isolation and functional analysis of Arabidopsis stressinducible NAC transcription factors that bind to a droughtresponsive cis-element in early responsive to dehydration stress 1 promoter. Plant Cell 16:2481-2498. doi:10.1105/tpc.104. 022699

Vandesompele J, De Preter K, Pattyn F, Poppe B, Van Roy N, De Paepe A, Speleman F (2002) Accurate normalization of real-time quantitative RT-PCR data by geometric averaging of multiple internal control genes. Genome Biol 3. doi:10.1186/gb-2002-37-research0034

Wankhade SD, Cornejo MJ, Mateu-Andrés I, Sanz A (2013) Morphophysiological variations in response to $\mathrm{NaCl}$ stress during vegetative and reproductive development of rice. Acta Physiol Plant 35:323-333

Zhang B, Pan X, Cobb GP, Anderson TA (2006) Plant microRNA: a small regulatory molecule with big impact. Dev Biol 289:3-16

Zhang ZH, Liu Q, Song HX, Rong XM, Abdelbagi MI (2012) Responses of different rice (Oryza sativa $\mathrm{L}$.) genotypes to salt stress and relation to carbohydrate metabolism and chlorophyll content. Afr J Agric Res 7:19-27

Zhong H, Guo QQ, Chen L, Ren F, Wang QQ, Zheng Y, Li XB (2012) Two Brassica napus genes encoding NAC transcription factors are involved in response to high-salinity stress. Plant Cell Rep 31:1991-2003. doi:10.1007/s00299-012-1311-3 